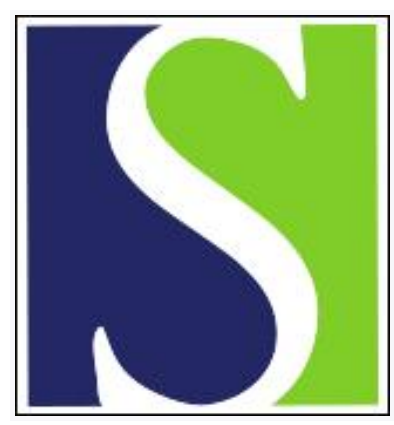

Scand J Work Environ Health 2000;26(5):436-442

https://doi.org/10.5271/sjweh.565

Issue date: Oct 2000

Chromosome aberrations in pesticide-exposed greenhouse workers

by Lander F, Knudsen LE, Gamborg MO, Järventaus H, Norppa H

The following article refers to this text: 2007;33(6):465-469

Key terms: biomarkers; fungicides; genotoxicity; growth regulator; insecticides; lymphocytes

This article in PubMed: www.ncbi.nlm.nih.gov/pubmed/11103843

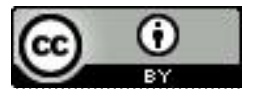




\title{
Chromosome aberrations in pesticide-exposed greenhouse workers
}

\author{
by Flemming Lander, PhD, ${ }^{1}$ Lisbeth E Knudsen, PhD, ${ }^{2}$ Michael 0 Gamborg, ${ }^{2}$ Hilkka Järventaus, ${ }^{3}$ Hannu \\ Norppa, $P h D^{3}$
}

\begin{abstract}
Lander F, Knudsen LE, Gamborg MO, Järventaus H, Norppa H. Chromosome aberrations in pesticide-exposed greenhouse workers. Scand J Work Environ Health 2000;26(5):436-442.
\end{abstract}

\begin{abstract}
Objectives The aim of this study was to investigate the possibility of subtoxic exposure to pesticides causing chromosome aberrations in greenhouse workers.

Methods In a cross-sectional and prospective study design chromosome aberration frequencies in cultured lymphocytes were examined for 116 greenhouse workers exposed to a complex mixture of almost 50 insecticides, fungicides, and growth regulators and also for 29 nonsmoking, nonpesticide-exposed referents.

Results The preseason frequencies of chromosome aberrations were slightly but not statistically significantly elevated for the greenhouse workers when they were compared with the referents. After a summer season of pesticide spraying in the greenhouses, the total frequencies of cells with chromosome aberrations were significantly higher than in the preseason samples $(\mathrm{P}=0.02)$ and also higher than for the referents $(\mathrm{P}=0.05)$. This finding was especially due to an increased number of cells with chromatid gaps between the first and second samples $(\mathrm{P}=0.001)$. The results may reflect an additive genotoxic effect of the spraying season, for which the use of insecticides and growth regulators (but not fungicides) culminates. The highest elevation in the risk of chromatid gaps was observed for persons who did not use gloves during re-entry activities such as nipping, cutting, pricking, and potting (risk ratio $2.88,95 \%$ confidence interval $1.63-5.11$ ).

Conclusions The present results suggest a genotoxic effect from a complex subtoxic occupational pesticide exposure. In general, the findings indicate the importance of personal protection, during high-exposure re-entry activities, in preventing pesticide uptake and genetic damage.
\end{abstract}

Key terms biomarkers, fungicides, genotoxicity, growth regulators, insecticides, lymphocytes.

In temperate countries, the most intense agricultural pesticide exposure is likely to occur in greenhouses with ornamental production. In Denmark, 6000 workers performing re-entry activities are potentially exposed. A minor group of workers occasionally and transitorily mix and apply pesticides.

During recent years only pesticides of low acute toxicity to humans have been used in Denmark, and safe work habits have been promoted by the authorities. Especially the personal protection and hygiene of applicators have been improved. This change is probably the main reason why pesticide poisonings have become extremely rare events in Denmark during the last few decades $(1,2)$. Hence the actual exposure of greenhouse workers probably occurs in re-entry activities such as cutting and trimming cultures recently treated with pesticides. The main route of uptake is through the skin, in particular on the hands and forearms, and some exposure may also occur orally (3-5).

While the acute toxic effects of overexposure to pesticides are well known, there is insufficient information on the possible genotoxic hazards that may arise from subtoxic occupational exposure $(6,7)$. Information about the mutagenicity of single pesticides or mixtures of pesticides is mainly derived from a variety of short-term tests, and mutagenic compounds have been found among all major categories of pesticides, including fungicides, insecticides and herbicides $(6-10)$. Several field studies of applicators and persons in highly exposed agricultural jobs have suggested a genotoxic risk $(11-20)$ although some of the investigations have given negative results $(21-25)$. The complexity and seasonal character

1 Danish Working Environment Authority, Copenhagen, Denmark.

2 Institute of Public Health, University of Copenhagen, Denmark.

3 Laboratory of Molecular and Cellular Toxicology, Department of Industrial Hygiene and Toxicology, Finnish Institute of Occupational Health, Helsinki, Finland.

Reprint requests to: Dr Flemming Lander, Danish Working Environment Authority, Landskronagade 33, 2100 Copenhagen $\emptyset$, Denmark. [E-mail: fla@Arbejdstilsynet.dk] 
of pesticide exposure and the variable pesticide preparations used make it difficult to compare the results of different studies.

The aim of this study was to investigate the possibility of subtoxic exposure to pesticides causing chromosome aberrations in greenhouse workers.

\section{Subjects and methods}

\section{Subjects}

The cytogenetic effects of pesticide exposure were investigated partly as a cross-sectional study among greenhouse workers and nonsmoking referents before the spraying season and partly as a prospective study through the resampling of greenhouse workers in the season in which the use of pesticides culminated.

The exposed group consisted of 116 healthy male greenhouse workers engaged in 30 floriculture-producing nurseries situated in Odense and Aarhus. None of the greenhouse workers had experienced an acute pesticide intoxication during the investigation period. The mean nursery area covered by glass was 17700 (range 500050500) $\mathrm{m}^{2}$.

A comprehensive questionnaire with self-completed information on medical, occupational, and life-style history was checked by a physician. For each exposed person, work habits were obtained in relation to re-entry activities including the use of protective gloves. Correct wearing or the intactness of the gloves was not registered. The owners, foremen, and applicators recorded information on all pesticide applications from October 1993 to October 1994 (type of pesticide, area).

The reference group consisted of 29 men who were members of an organic association and did not use pesticides.

The characteristics of the referents and the exposed nonsmoking, smoking, and total subjects are shown in table 1 . The referents were older than the greenhouse workers and did not smoke. Drinking habits and the consumption of caffeine were not markedly different in the 2 groups, but slightly fewer greenhouse workers than referents had been exposed to X-rays during the last year. Among the greenhouse workers drinking habits, the consumption of caffeine, exposure to X-rays, and age were not markedly different between the smokers and nonsmokers. Except for greenhouse workers who were examined postseasonally, the data concerning the consumption of tobacco, alcohol, and caffeine refer to the time of the first blood samples. We assumed that the individual consumption was constant over time. The nonsmokers included a few ex-smokers who had not smoked for at least 1 year.

\section{Blood samples and analysis}

Five-milliliter samples of heparinized peripheral blood were collected and shipped by air to Finland. The shipments were labeled "Do not X-ray", "Keep Cool — Do not Freeze", and each batch reached the Finnish Institute of Occupational Health the next morning, approximately 24 hours after the sampling.

Three rounds of sample collection were arranged, the preseason samples being collected from 110 pesticide workers in March 1994 and the postseason samples from 89 workers in October 1994. A total of 116 greenhouse workers participated in the study. Paired samples were obtained for 83 persons. In March 1995, altogether 29 samples were collected from the nonsmoking referents.

Two whole-blood lymphocyte cultures per sample were established in cell culture tubes (Falcon 3033) and were cultured and harvested as described previously (26). One hundred metaphases were analyzed from microscopic preparations for chromosome aberrations using the Cytoscan Cytogenetics Image Analysis System CS2 for metaphase finding. The identity or exposure status of the subjects was not revealed to the analyzing laboratory before the analyses were completed. The analyses were started only after all the slides were available. All the analyses for chromosome aberrations were performed on coded slides by 1 observer. The aberrations found were classified as chromatid- and chromosome-type gaps, breaks, and exchanges. The number of cells with these types of aberrations and the total number of cells with chromatid-type, chromosome-type, and any type of aberrations, excluding or including gaps, were calculated.

\section{Exposure assessment}

The pesticides used in the greenhouses during the preceding 3 months before the first blood sampling and between the first and second sampling consisted of a mixture of almost 50 different compounds, including insecticides, fungicides, and growth regulators, whereas the application of herbicides was negligible. Table 2 shows the pesticides most commonly used.

Table 1. Characterization of the study groups.

\begin{tabular}{|c|c|c|c|c|c|c|c|}
\hline \multirow[t]{2}{*}{$\begin{array}{l}\text { Study } \\
\text { group }\end{array}$} & \multicolumn{2}{|c|}{$\begin{array}{l}\text { Caffeine intake } \\
\text { (g/week) }\end{array}$} & \multicolumn{2}{|c|}{$\begin{array}{r}\text { Alcohol intake } \\
\text { (drinks/week) }\end{array}$} & \multirow{2}{*}{$\begin{array}{c}\text { X-ray } \\
\text { exposure } \\
\text { in past } \\
\text { year }\end{array}$} & \multicolumn{2}{|c|}{$\begin{array}{c}\text { Age } \\
\text { (years) }\end{array}$} \\
\hline & Mean & Range & Mean & Range & & Mean & Range \\
\hline $\begin{array}{l}\text { Referents (all } \\
\text { nonsmokers) } \\
(\mathrm{N}=29)\end{array}$ & 3.7 & $2.3-15.4$ & 9 & $0-25$ & 22 & 38 & $30-53$ \\
\hline $\begin{array}{l}\text { Greenhouse } \\
\text { workers }\end{array}$ & & & & & & & \\
\hline $\begin{array}{l}\text { Nonsmokers } \\
(\mathrm{N}=72)\end{array}$ & rs 3.2 & $0-12.8$ & 10 & $0-38$ & 12 & 29 & $19-43$ \\
\hline $\begin{array}{l}\text { Smokers } \\
(N=44) \\
\text { All }(N=116)\end{array}$ & $\begin{array}{l}3.7 \\
3.4\end{array}$ & $\begin{array}{l}0-11.5 \\
0-12.8\end{array}$ & $\begin{array}{l}11 \\
10\end{array}$ & $\begin{array}{l}0-44 \\
0-44\end{array}$ & $\begin{array}{l}11 \\
12\end{array}$ & $\begin{array}{l}27 \\
28\end{array}$ & $\begin{array}{l}19-41 \\
19-43\end{array}$ \\
\hline
\end{tabular}


Table 2. Insecticides, fungicides, and growth regulators most commonly used in the greenhouses studied.

\begin{tabular}{lc}
\hline Type of pesticide & $\begin{array}{c}\text { Number of } \\
\text { greenhouses }\end{array}$ \\
\hline Insecticides & \\
Pirimicarb & 26 \\
Methomyl & 14 \\
Delthamethrin & 14 \\
Endosulfan & 12 \\
Clorpyrifos & 9 \\
Buprofezin & 9 \\
Dienochlor & 8 \\
Fenpropathrin & 7 \\
Alfacypermethrin & 6 \\
Amitraz & 4 \\
Fungicides & \\
Benomyl & 16 \\
Iprodion & 16 \\
Chlorothalonil & 13 \\
Carbendazim & 8 \\
Vinclozolin & 8 \\
Thiram & 4 \\
Growth regulators & \\
Chlormequatchlorid & 23 \\
Daminozid & 17 \\
Praclobutrazol & 12 \\
\hline
\end{tabular}

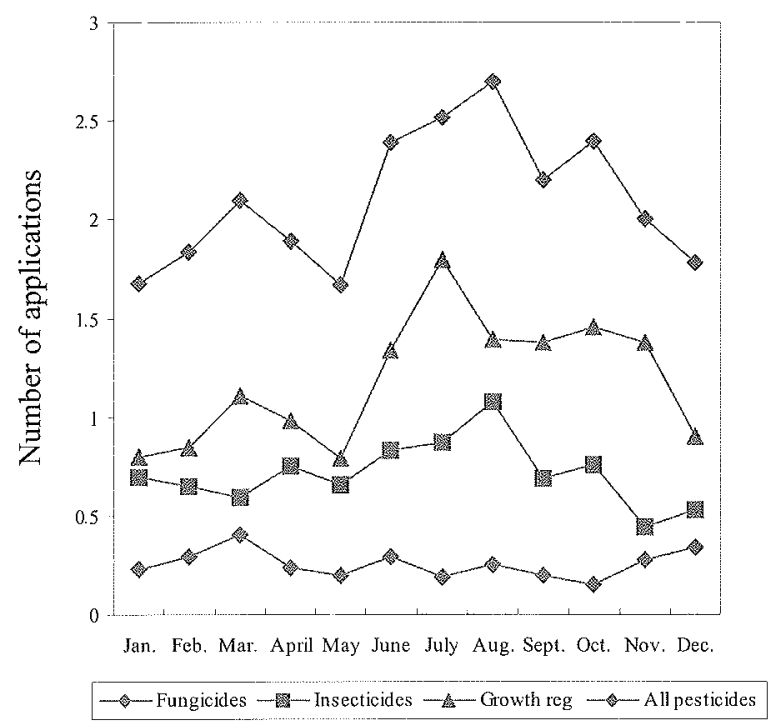

Figure 1. Mean number of pesticide applications per area units in all the greenhouses according to the month of the year. (reg = regulators)

Figure 1 shows the monthly mean number of pesticide treatments per area units in the greenhouses studied. Most applications concerned growth regulators, followed by insecticides; July and August were the busiest months. The use of fungicides remained low throughout the year, with a small peak in April.

The prospective study was based on the overall assumption that exposure to pesticides is substantially higher during the spraying season from May to August (figure 1), although the greenhouse workers are exposed to pesticides throughout the year. The job tasks of the greenhouse workers were many, including pricking, potting, nipping, cutting cuttings, spacing cultures, working with pot machines, moving tables, packing, care, and surveillance. It was assumed that some of these tasks (eg, nipping, cutting, pricking, and potting) imply high-dermal exposure, especially due to the transfer of pesticide residues from culture to hands and forearms. The effects of current seasonal exposure to pesticides, particularly hands and forearms, was assessed by comparison of postseason and preseason samples (overall effect of the spraying season) and by classifying the greenhouse workers according to the use of protective gloves during reentry job tasks (yes-no).

\section{Data analysis and statistics}

The discrete numbers of cells with various types of chromosome aberrations were tested for Poisson distribution. The analysis showed no sign of a positive correlation at all between the pre- and postseason on the number of cells with any type of chromosome aberration. The 83 paired samples (pre- and postseason) were found to be independent, according to the bivariate Poisson distribution, which allows a positive correlation between paired samples. In the bivariate Poisson model for the total number of cells with chromosome aberrations (gaps included), the estimated correlation was 0 , and the Pearson correlation coefficient was -0.26 (27).

To control for possible confounders, we analyzed the data using a multiple log-linear Poisson regression model. When the nonsmoking greenhouse workers were compared with the referents (all nonsmokers), the model included pesticide exposure (yes or no), age (years), and caffeine intake (grams/week). The effect of the spraying season and glove use was studied for the greenhouse workers in a model including the sampling (preseason or postseason), use of gloves (yes or no), current smoking status (yes or no), age, and caffeine intake. Among the greenhouse workers, caffeine intake positively influenced the total frequency of aberrant cells, including gaps, and the frequency of cells with chromatid gaps in the Poisson model including age, caffeine, smoking, season, and the use of protective gloves. In the reference group, the effect of caffeine intake did not show clear effects. When greenhouse workers not consuming caffeine were defined as referents, the intake of 1 gram of caffeine per week increased the rate ratio for the total frequency of aberrant cells, gaps included, to 1.05 for the pesticide workers. Age and smoking had no independent influence on the frequency of cells with chromosome aberrations. The SAS/STAT software package (version 6.12 , 4th edition, volume 2 , SAS Institute Inc., Cary, NC, USA) was used for the statistical analyses. 


\section{Results}

The results of the cytogenetic analysis of the 2 samplings of the greenhouse workers and the single sampling of the referents are reported in table 3 separately for the smokers and nonsmokers. In the cross-sectional study, concerning only nonsmokers, the frequencies of cells with chromatid gaps, chromosome-type exchanges, and total chromosome-type aberrations were slightly, but not statistically significantly higher in the first samples of the greenhouse workers than in the samples of the referents.

In the prospective study, including both the smoking and nonsmoking greenhouse workers (table 3 ), the total frequencies of cells with chromosome aberrations (gaps included) were higher in the second than in the first sampling $(\mathrm{P}=0.02)$. This effect was seen in several aberration categories, but was particularly clear for the number of cells with chromatid gaps $(\mathrm{P}=0.001)$ and the total number of chromatid aberration gaps included ( $\mathrm{P}=0.05)$. On the other hand, the number of cells with chromosometype exchanges was higher preseasonally than postseasonally $(P=0.01)$. In the postseason samples of the nonsmoking greenhouse workers, the frequency of cells with chromatid gaps was higher than in the samples from the (nonsmoking) referents $(\mathrm{P}=0.05)$.

The crude results of the cytogenetic analysis of the 2 samplings of the greenhouse workers stratified according to the use of protective gloves during re-entry activities and smoking are shown in table 4. For smoking nonglove users, a significant increase in the total frequency of cells with chromosome aberrations (gaps included) was found for the postseason values when they were compared with the preseason values $(P=0.04)$, whereas the excess was not statistically significant for the nonsmoking nonglove users $(\mathrm{P}=0.39)$ or, regardless of smoking habits, the workers who had worn gloves $(P=0.17)$. The excess in the total frequency of cells with chromosome aberrations was, as already shown, mainly due to an increase in the frequency of cells with chromatid gaps. A separate analysis comparing pre- and postseason chromatid gaps revealed an overall increased risk ratio for greenhouse workers who had not used gloves during re-entry activities [risk ratio (RR) $2.88,95 \%$ CI $1.63-5.11$ ] in the Poisson regression model correcting for the effects of age, caffeine intake, and smoking. The increased risk was observed regardless of smoking, although the smokers showed a higher risk ratio (RR 7.86, 95\% CI 1.7236.0 ) than the nonsmokers (RR 2.21, 95\% CI 1.184.15 ), mainly due to their very low value in the preseason sampling. The excess was not statistically significant for the workers who had worn gloves, even though smokers in this group showed a risk ratio of 1.71 (95\% CI $0.92-3.19$ ). The smoking glove users actually had a higher mean frequency of cells with gaps than the nonusers in both samplings.

\section{Discussion}

Our study suggests that greenhouse workers employed in ornamental production have an elevated frequency of cells with chromosome aberrations, especially chromatid gaps, in their peripheral lymphocytes postseasonally when compared with their preseason values and the values of referents. The postseason samples were taken from

Table 3. Frequencies of cells with structural chromosome aberrations in peripheral lymphocytes of the greenhouse workers and referents.

\begin{tabular}{|c|c|c|c|c|c|c|c|c|c|c|c|c|c|c|c|c|c|c|c|c|c|}
\hline \multirow[t]{4}{*}{ Study group } & \multirow[t]{4}{*}{ N } & \multicolumn{8}{|c|}{ Chromatid-type $e^{\mathrm{a}, \mathrm{b}}$} & \multicolumn{8}{|c|}{ Chromosome-type $e^{a, b}$} & \multicolumn{4}{|c|}{ Total } \\
\hline & & \multirow{2}{*}{\multicolumn{2}{|c|}{ Gaps (\%) }} & \multirow{2}{*}{\multicolumn{2}{|c|}{ Breaks (\%) }} & \multicolumn{4}{|c|}{ Total } & \multirow{2}{*}{\multicolumn{2}{|c|}{$\begin{array}{c}\text { Breaks } \\
(\%)\end{array}$}} & \multirow{2}{*}{\multicolumn{2}{|c|}{$\begin{array}{c}\text { Exchanges } \\
(\%)\end{array}$}} & \multicolumn{4}{|c|}{ Total } & \multirow{2}{*}{\multicolumn{2}{|c|}{$\begin{array}{c}\text { Gaps } \\
\text { excluded } \\
(\%)\end{array}$}} & \multirow{2}{*}{\multicolumn{2}{|c|}{$\begin{array}{c}\text { Gaps } \\
\text { included } \\
(\%)\end{array}$}} \\
\hline & & & & & & \multicolumn{2}{|c|}{ Gaps - } & \multicolumn{2}{|c|}{ Gaps + } & & & & & \multicolumn{2}{|c|}{ Gaps - } & \multicolumn{2}{|c|}{ Gaps + } & & & & \\
\hline & & Mean & SD & Mean & SD & Mean & $\mathrm{SD}$ & Mean & SD & Mean & $S D$ & Mean & SD & Mean & SD & Mean & SD & Mean & $\mathrm{SD}$ & Mean & SD \\
\hline $\begin{array}{l}\text { Nonsmoking } \\
\text { referents }\end{array}$ & 29 & 0.31 & 0.60 & 1.00 & 0.80 & 1.03 & 0.82 & 1.34 & 1.14 & 0.17 & 0.38 & 0.10 & 0.31 & 0.28 & 0.45 & 0.28 & 0.45 & 1.31 & 0.85 & 1.62 & 1.15 \\
\hline Greenhouse work & kers & & & & & & & & & & & & & & & & & & & & \\
\hline $\begin{array}{c}\text { Preseason } \\
\text { Smokers }\end{array}$ & 42 & 0.48 & 0.63 & 0.74 & 094 & 0.81 & 0.99 & 129 & 1.13 & 0.14 & 0.42 & 0.33 & 0.57 & 0.48 & 0.67 & 0.52 & 067 & 129 & 131 & 181 & 142 \\
\hline Nonsmokers & 68 & 0.56 & 0.70 & 0.90 & 0.92 & 0.91 & 0.93 & 1.46 & 1.08 & 0.18 & 0.42 & 0.28 & 0.59 & 0.44 & 0.78 & 0.47 & 0.78 & 1.34 & 1.19 & 1.91 & 1.24 \\
\hline All & 110 & 0.53 & 0.67 & 0.84 & 0.92 & 0.87 & 0.95 & 1.39 & 1.10 & 0.16 & 0.42 & 0.30 & 0.58 & 0.45 & 0.74 & 0.49 & 0.74 & 1.32 & 1.23 & 1.87 & 1.31 \\
\hline Postseason & & & & & & & & & & & & & & & & & & & & & \\
\hline Smokers & 31 & 1.10 & 0.83 & 1.10 & 0.98 & 1.13 & 0.99 & 2.16 & 1.13 & 0.13 & 0.34 & 0.19 & 0.40 & 0.32 & 0.54 & 0.42 & 0.56 & 1.45 & 1.26 & 2.55 & 1.39 \\
\hline Nonsmokers & 58 & 0.91 & 0.88 & 0.97 & 0.99 & 1.00 & 0.99 & 1.90 & 1.21 & 0.28 & 0.49 & 0.09 & 0.34 & 0.35 & 0.58 & 0.38 & 0.62 & 1.33 & 1.18 & 2.24 & 1.49 \\
\hline All & 9 & 0.98 & 0.87 & 1.01 & 0.98 & 1.04 & 0.99 & 1.99 & 1.18 & 0.22 & 0.45 & 0.12 & 0.36 & 0.34 & 0.56 & 0.39 & 0.60 & 1.37 & 1.20 & 2.34 & 1.45 \\
\hline
\end{tabular}

a Chromatid-type exchanges and chromosome-type gaps were rare and have not been shown separately.

- Referents versus greenhouse workers prior to the season, nonsmokers; chromatid gaps $(P=0.09)$, chromosome exchanges ( $P=0.07)$; referents versus greenhouse workers after the season, nonsmokers: total + gaps $(P=0.05)$, total chromatid-type aberrations+ gaps $(P=0.06)$, chromatid gaps $(P=0.0007)$; preseason versus postseason, all: total + gaps $(P=0.02)$, total chromatid-type aberrations + gaps $(P=0.05)$, chromatid gaps $(P=0.001)$, chromosome exchanges $(\mathrm{P}=0.01)$. 
Table 4. Frequencies of cells with structural chromosome aberrations in peripheral lymphocytes of the greenhouse workers exposed to pesticides. Whole-blood lymphocyte cultures were cultured for 48 hours, and 100 metaphases were scored per person. ${ }^{\mathrm{a}}$

\begin{tabular}{|c|c|c|c|c|c|c|c|c|c|c|c|c|c|c|c|c|c|c|c|c|c|}
\hline \multirow{4}{*}{$\begin{array}{l}\text { Use of } \\
\text { protective } \\
\text { gloves }\end{array}$} & \multirow[t]{4}{*}{$N$} & \multicolumn{8}{|c|}{ Chromatid-type $\mathrm{a}^{\mathrm{a}, \mathrm{b}}$} & \multicolumn{8}{|c|}{ Chromosome-type ${ }^{\mathrm{a}, \mathrm{b}}$} & \multicolumn{4}{|c|}{ Total } \\
\hline & & \multirow{2}{*}{\multicolumn{2}{|c|}{ Gaps (\%) }} & \multirow{2}{*}{\multicolumn{2}{|c|}{ Breaks (\%) }} & \multicolumn{4}{|c|}{ Total } & \multirow{2}{*}{\multicolumn{2}{|c|}{$\begin{array}{c}\text { Breaks } \\
(\%)\end{array}$}} & \multirow{2}{*}{\multicolumn{2}{|c|}{$\begin{array}{c}\text { Exchanges } \\
(\%)\end{array}$}} & \multicolumn{4}{|c|}{ Total } & \multirow{2}{*}{\multicolumn{2}{|c|}{$\begin{array}{l}\text { Gaps } \\
\text { excluded } \\
(\%)\end{array}$}} & \multirow{2}{*}{\multicolumn{2}{|c|}{$\begin{array}{l}\text { Gaps } \\
\text { included } \\
(\%)\end{array}$}} \\
\hline & & & & & & \multicolumn{2}{|c|}{ Gaps - } & \multicolumn{2}{|c|}{ Gaps + } & & & & & \multicolumn{2}{|c|}{ Gaps - } & \multicolumn{2}{|c|}{ Gaps + } & & & & \\
\hline & & Mean & SD & Mean & $\mathrm{SD}$ & Mean & SD & Mean & SD & Mean & $S D$ & Mean & SD & Mean & SD & Mean & SD & Mean & SD & Mean & SD \\
\hline \multicolumn{22}{|l|}{ Yes } \\
\hline \multicolumn{22}{|l|}{ Preseason } \\
\hline Smokers & 25 & 0.72 & 0.68 & 0.60 & 0.76 & 0.64 & 0.76 & 1.36 & 1.04 & 0.16 & 0.47 & 0.36 & 0.64 & 0.52 & 0.77 & 0.60 & 0.76 & 1.16 & 1.18 & 1.96 & 1.34 \\
\hline Nonsmokers & 38 & 0.63 & 0.71 & 0.87 & 0.96 & 0.87 & 0.96 & 1.47 & 1.08 & 0.11 & 0.31 & 0.21 & 0.62 & 0.29 & 0.69 & 0.32 & 0.70 & 1.16 & 1.22 & 1.79 & 1.23 \\
\hline All & 63 & 0.67 & 0.70 & 0.76 & 0.89 & 0.78 & 0.89 & 1.43 & 1.06 & 0.13 & 0.38 & 0.27 & 0.63 & 0.38 & 0.73 & 0.43 & 0.73 & 1.16 & 1.19 & 1.86 & 1.27 \\
\hline \multicolumn{22}{|c|}{ 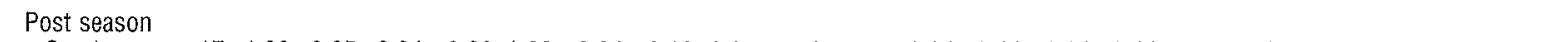 } \\
\hline Smokers & 17 & 1.30 & 0.85 & 0.94 & 0.90 & 1.00 & 0.94 & 2.18 & 0.95 & 0 & & 0.24 & 0.44 & 0.24 & 0.44 & 0.35 & 0.49 & 1.24 & 1.09 & 2.47 & 1.12 \\
\hline Nonsmokers & 31 & 0.77 & 0.92 & 0.97 & 0.95 & 0.97 & 0.95 & 1.74 & 1.18 & 0.35 & 0.55 & 0.06 & 0.36 & 0.39 & 0.67 & 0.39 & 0.67 & 1.32 & 1.25 & 2.10 & 1.58 \\
\hline All & 48 & 0.96 & 0.92 & 0.96 & 0.92 & 0.98 & 0.93 & 1.90 & 1.12 & 0.23 & 0.47 & 0.13 & 0.39 & 0.33 & 0.60 & 0.38 & 0.61 & 1.29 & 1.18 & 2.23 & 1.43 \\
\hline \multicolumn{22}{|l|}{ No } \\
\hline \multicolumn{22}{|l|}{ Preseason } \\
\hline Smokers & 17 & 0.12 & 0.33 & 0.94 & 1.14 & 1.06 & 1.25 & 1.18 & 1.29 & 0.12 & 0.33 & 0.29 & 0.47 & 0.41 & 0.51 & 0.41 & 0.51 & 1.47 & 1.50 & 1.59 & 1.54 \\
\hline Nonsmokers & 30 & 0.47 & 0.68 & 0.93 & 0.87 & 0.97 & 0.89 & 1.43 & 1.10 & 0.27 & 0.52 & 0.37 & 0.56 & 0.63 & 0.85 & 0.67 & 0.84 & 1.57 & 1.13 & 2.07 & 1.26 \\
\hline All & 47 & 0.34 & 0.60 & 0.94 & 0.96 & 1.00 & 1.02 & 1.34 & 1.17 & 0.21 & 0.46 & 0.34 & 0.52 & 0.55 & 0.75 & 0.57 & 0.74 & 1.53 & 1.27 & 1.89 & 1.37 \\
\hline \multicolumn{22}{|c|}{ 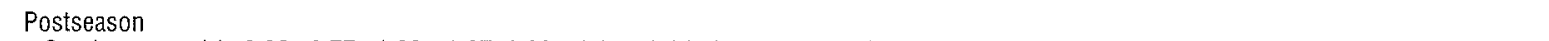 } \\
\hline Smokers & 14 & 0.86 & 0.77 & 1.29 & 1.07 & 1.29 & 1.07 & 2.14 & 1.35 & 0.29 & 0.47 & 0.14 & 0.36 & 0.43 & 0.65 & 0.50 & 0.65 & 1.71 & 1.44 & 2.64 & 1.69 \\
\hline Nonsmokers & 27 & 1.07 & 0.83 & 0.96 & 1.06 & 1.04 & 1.06 & 2.07 & 1.24 & 0.19 & 0.40 & 0.11 & 0.32 & 0.30 & 0.47 & 0.37 & 0.56 & 1.33 & 1.11 & 2.41 & 1.39 \\
\hline All & 41 & 1.00 & 0.81 & 1.07 & 1.06 & 1.12 & 1.05 & 2.10 & 1.26 & 0.22 & 0.42 & 0.12 & 0.33 & 0.34 & 0.53 & 0.41 & 0.59 & 1.46 & 1.22 & 2.49 & 1.49 \\
\hline
\end{tabular}

a Preseason versus postseason, no glove users, all: total + gaps $(P=0.06)$, chromosome exchange $(P=0.03)$, total chromatid + gaps $(P=0.07)$, chromatid gaps $(P=0.0001)$; preseason versus postseason, glove users, all: chromosome exchanges $(P=0.06)$, total chromatid + gaps $(P=0.06)$ chromatid gaps $(P=0.09)$.

the exposed group at the end of a period in which the use of insecticides and growth regulators, but not fungicides, culminated. Our findings indicate that continuous subtoxic pesticide exposure induces genotoxic damage during the intense pesticide use of the summer spraying season. The effect of the spraying season was primarily observed for the workers who had not used gloves during re-entry activities when performing nonspraying job tasks involving high-dermal exposure, such as nipping, cutting, pricking, and potting. These findings agree with the generally accepted assumption that exposure to pesticides during re-entry activities mostly occurs through the hands and forearms, pesticides being taken up either percutaneously or orally (3-5). Although we could not show any clear effects of smoking on chromosome aberrations in general, the greenhouse workers who had not used protective gloves and were current smokers showed a much higher risk ratio of chromatid gaps than the nonsmokers did. Thus smoking may potentiate the genotoxic effects of pesticides, possibly due to its own genotoxic effects or to an increase in oral exposure to pesticides. During smoking, pesticide residues on fingers may reach the lips and be swallowed. In many earlier studies, smoking has been observed to increase chromosome damage $(21,26)$, but this effect may require some time to be established and may not be obvious in young subjects such as our greenhouse workers.

Even though the genotoxic effects primarily showed a relationship to the re-entry activities of greenhouse workers, the results may have been influenced by those who temporarily performed the in-season application of pesticides, too. In fact, the degree of protection and the duration of the exposure during spraying have been previously shown to display an association with the amount of individual pesticide uptake measured by serum cholinesterase activities and the frequency of sister chromatid exchange in lymphocytes $(1,2,17)$. But due to very high Danish standards of personal protection and the hygiene of applicators, we assumed that pesticide exposure during mixing and spraying in general are very low or negligible under actual work conditions. Nevertheless, the findings indicate the importance of protection when spraying and during high-exposure re-entry activities such as the cutting and trimming of cultures, in preventing pesticide uptake and genetic damage.

As the genotoxic effect was mainly seen in the form of chromatid gaps, the results may also suggest that gaps represent a reversible form of genetic damage which reflects relatively recent genotoxic exposure. Chromatidtype gaps are probably formed in the cell culture from DNA (deoxyribonucleic acid) lesions (such as adducts) that preexist in vivo. We only included the undislocated lesions that were wider than a chromatid but less wide than 2 chromatids as gaps. Smaller discontinuities were not recorded. As some laboratories would score our gaps as breaks, these aberrations can be considered to represent a clear class of damage, unlike gaps that have no defined lower size limit. 
Several previous studies have observed increased chromosome aberrations and other cytogenetic effects in cultured lymphocytes from pesticide-exposed workers $(11-20)$. The majority of the studies have primarily reported increased genotoxic damage in suboptimally or improperly protected applicators. Other similar studies have failed to detect genotoxic effects $(21-25)$. This contradiction is probably the result of variation in pesticide exposure among the workers because of differences in crops (eg, field or indoor crops), work habits, and especially the wide variety of pesticides used.

Given the complex exposure to almost 50 pesticides, it is not possible to state which agents may have been responsible for the observed induction of chromosome aberrations in the greenhouse workers. Some of the organochlorine insecticides, organophosphates, and carbamates, in addition to some fungicidal groups of pesticides, used in the present study have been reported to induce cytogenetic effects in experimental test systems (6-10). To our knowledge, there is no information on the genotoxic hazard of growth regulators. In our study the use of pesticides increased during the spraying season, mainly due to an increased application of growth regulators and insecticides. Fungicides were used at a low rate throughout the year.

Smoking, age, caffeine intake, and alcohol intake are background and life-style variables that may influence the frequency of chromosome aberrations. All these factors were considered in our analysis, but none of them were responsible for the observed differences between the exposed and reference groups or between the estimated exposure level groups. In fact only caffeine intake seemed to have an independent effect on chromosome aberrations, mainly chromosome-type breaks. Caffeine consumption has earlier been described to be associated with an increased rate of micronuclei in blood erythrocytes of splenectomized human subjects (28).

Although the genotoxic mechanisms leading to an increased number of chromosome aberrations are not known in detail, chromosomal analysis has been adopted as a sensitive indicator of genotoxicity (29). Increased cancer risk has been associated with increased levels of chromosome aberrations, while a similar conclusion has not been available for sister chromatid exchanges or micronuclei $(30,31)$. Epidemiologic data indicate that pesticide exposure is associated with an increased risk of certain malignant neoplasms (eg, lung cancer, neoplasms of lymphatic and hematopoietic tissue, and soft tissue sarcomas) (7). The evidence that occupational exposures to nonarsenical insecticides entail an excess risk of lung cancer was evaluated as "limited" by the International Agency for Research on Cancer (7), and the exposures were classified as probably carcinogenic to humans. In a recent cohort study, an increased risk of lymphatic and hematopoietic neoplasms and soft tissue sarcomas was observed among 4000 Danish gardeners. The study cohort primarily comprised greenhouse workers (32).

In conclusion, the results suggest that subtoxic exposure to pesticides in re-entry activities increases the frequency of chromosome aberrations in human lymphocytes. The clearest exposure-related effects were observed for greenhouse workers who did not use gloves during re-entry job tasks. As work in greenhouses appears to involve exposure to genotoxic agents capable of damaging human DNA, workers using pesticides should take adequate protective measures to prevent long-term effects such as neoplasms.

\section{Acknowledgments}

The authors wish to thank Annette Abell, MD, for organizing the blood samplings and Ghita Falck, MSc, for help with the processing of the samples.

This study was financially supported by the Danish Environmental Protection Agency.

\section{References}

1. Lander F, Hinke K. Indoor application of anti-cholinesterase agents and the influence of personal protection on uptake. Arch Environ Contam Toxicol 1992;22:163-6.

2. Lander F, Lings S. Plasma cholinesterase variation among greenhouse workers, fruitgrowers and slaughtermen. $\mathrm{Br} J$ Ind Med 1991;48:164-6.

3. Brouwer R, Marquart $\mathbf{H}$, Mik G, Van Hemmen JJ. Risk assessment of dermal exposure of greenhouse workers to pesticides after re-entry. Arch Environ Contam Toxicol 1992; 23:273-80.

4. Kangas J, Laitinen S, Jauhiainen A, Savolainen K. Exposure of sprayers and plant handlers to mevinphos in Finnish greenhouses. Am Ind Hyg Assoc J 1993;54:150 - 7.

5. Lander F, Pike E, Hinke K, Brock A, Nielsen JB. Anticholinesterase agents uptake during cultivation of greenhouse flowers. Arch Environ Contam Toxicol 1992;22:159-62.

6. Hayes WJ, Laws ER. Handbook of pesticide toxicology. San Diego (CA): Academic Press Inc, 1991.

7. International Agency for Research on Cancer (IARC). Occupational exposures in insecticide application and some pesticides. Lyon: IARC, 1991. IARC monographs on the evaluation of carcinogenic risks to humans, vol 53.

8. World Health Organization (WHO). Carbamate pesticides: a general introduction. Geneva: WHO, 1986. Environmental health criteria, no 64

9. World Health Organization (WHO). Organophosphorus insecticides: a general introduction. Geneva: WHO, 1986. Environmental health criteria, no 63 .

10. World Health Organization (WHO). Dithiocarbamate pesticides, ethylenethiourea, propylenethiourea: a general introduction. Geneva: WHO, 1988. Environmental health criteria, no 78.

Scand J Work Environ Health 2000, vol 26, no 5 
11. Bolognesi C, Parrini M, Reggiardo G, Merlo F, Bonassi S. Biomonitoring of workers exposed to pesticides. Int Arch Occup Environ Health 1993;65:185-7.

12. Carbonell E, Xamena N, Creus A, Marcos R. Cytogenetic biomonitoring in a Spanish group of agricultural workers exposed to pesticides. Mutagenesis 1993;8:511-7.

13. Dulout FN, Pastori MC, Olivero OA, Gonzalez C, Loria D, Matos E, et al. Sister chromatid exchanges and chromosomal aberrations in a population exposed to pesticides. Mutat Res $1985 ; 143: 237-44$

14. Jablonická A, Poláková H, Jarmila K, Vargová. Analysis of chromosome aberrations and sister-chromatid exchange in peripheral lymphocytes of workers with occupational exposure to the mancozeb-containing fungicide Novozir Mn80. Mutat Res 1989;224:143-6.

15. Kourakis A, Mouratidou M, Kokkinos G, Barbouti A, Kotsis A, Mourelatos D, et al. Frequencies of chromosomal aberrations in pesticide sprayers working in plastic houses. Mutat Res 1992;279:145-8

16. Kourakis A, Mouratidou M, Barbouti A, Dimikiotou M. Cytogenetic effects of occupational exposure in the peripheral blood lymphocytes of pesticide sprayers. Carcinogenesis 1996;17:99-101.

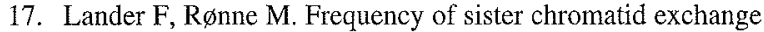
and hematological effects in pesticide-exposed greenhouse sprayers. Scand J Work Environ Health 1995;21:283-8.

18. Rupa DS, Reddy PP, Reddi O. Clastogenic effects of pesticides in peripheral lymphocytes of cotton-field workers. Mutat Res 1991;261:177-80.

19. Yoder J, Watson M, Benson WW. Lymphocyte chromosome analysis of agricultural workers during extensive occupational exposure to pesticides. Mutat Res 1973;21:335-40.

20. Falck GC-M, Hirvonen A, Scarpato R, Saarikoski S, Migliore $\mathrm{L}$, Norppa H. Micronuclei in blood lymphocytes and genetic polymorphism for GSTM1, GSTT1 and NAT2 in pesticideexposed greenhouse workers. Mutat Res 1999;441:225-37.

21. Scarpato R, Hirvonen A, Migliore L, Falck G, Norppa H. Influence of GSTM1 and GSTT1 polymorphisms on the frequency of chromosome aberrations in lymphocytes of smokers and pesticide-exposed greenhouse workers. Mutat Res 1997;389:227-35.

22. Scarpato R, Migliore L, Hirvonen A, Falck G, Norppa H.
Cytogenetic monitoring of occupational exposure to pesticides: characterization of GSTM1, GSTT1, and NAT2 genotypes. Environ Mol Mutagen 1996;27:263-9.

23. Carbonell E, Puig M, Xamena N, Creus A, Marcos R. Sister chromatid exchange in lymphocytes of agricultural workers exposed to pesticides. Mutagenesis 1990;5:403 - 5 .

24. Gomez-Arroyo $\mathrm{S}$, Noriega-Aldana $\mathrm{N}$, Osorio A, Galicia F Ling S, Villalobos-Pietrini R. Sister-chromatid exchange analysis in a rural population of Mexico exposed to pesticides. Mutat Res 1992;281:173—9.

25. de Casia Stocco R, Becak CW, Gaeta R, Rabello-Gay MN Cytogenetic studies of workers exposed to methyl parathion Mutat Res 1982;103:71-6.

26. Valjus J, Norppa H, Järventaus H, Sorsa M, Nykyri E, Salomaa $\mathrm{S}$, et al. Analysis of chromosomal aberrations, sister chromatid exchanges and micronuclei among power linesmen with long-term exposure to $50 \mathrm{~Hz}$ electromagnetic fields. Radiat Environ Biophys 1994;32:325-36.

27. Johnson NL, Kotz S, Balakrishnan N. Distributions in statistics, discrete multivariate distributions. New York(NY): John Wiley \& sons, 1997

28. MacGregor JT. Dietary factors affecting spontaneous chromosomal damage in man. Prog Clin Biol Res 1990;347:13953.

29. Sorsa M, Ojajärvi A, Salomaa S. Cytogenetic surveillance of workers exposed to genotoxic chemicals. Teratogen Carcinog Mutagen 1990;10:215-21.

30. Hagmar L, Brøgger A, Hansteen I-L, Heim S, Högstedt B, Knudsen $\mathbf{L}$, et al. Cancer risk in humans predicted by increased levels of chromosomal aberrations in lymphocytes: Nordic Study Group on the Health Risk of Chromosome Damage. Cancer Res 1994;54:2919-22.

31. Hagmar L, Bonassi S, Strömberg U, Brøgger A, Knudsen L, Norppa H, Reuterwall C, et al. Chromosomal aberrations in lymphocytes predict human cancer - a report from the European Study Group on Cytogenetic Biomarkers and Health (ESCH). Cancer Res 1998;58:4117-21.

32. Hansen ES, Hasle H, Lander F. A cohort study on cancer incidence among Danish gardeners. Am J Ind Med 1992; 21:651-60.

Received for publication: 23 April 1999 